\title{
Changes in Copepod Community Between Two Contrasting Samplings in a Highly Polluted Mediterranean Coastal Zone (Sfax Bay, Tunisia)
}

\author{
Salma Kmiha Megdiche ${ }^{1}$, Zaher Drira ${ }^{1 *}$, Marc Pagano $^{2}$ and Habib Ayadi ${ }^{1}$ \\ ${ }^{1}$ LR18E530 Marine Biodiversity and Environment, Department of Life Sciences, University of Sfax, Tunisia \\ ${ }^{2}$ Aix Marseille University, CNRS/INSU, University of Toulon, Mediterranean Institute of Oceanography, France
}

Submission: June 21, 2019; Published: July 24, 2019

Corresponding author: Zaher Drira, LR18E530 Marine Biodiversity and Environment, Department of Life Sciences, Sfax Faculty of Sciences, University of Sfax, Soukra Road Km 3.5. BP 1171 - PO Box 3000 Sfax, Tunisia

\begin{abstract}
Changes of taxonomic composition, morphology (total length) and reproductive mode of copepod assemblages between the cold and warm periods were studied in the Southern coast of Sfax, in relation with environmental factors and pollution degree (heavy metal concentration). Salinity, temperature and heavy metal concentration seem to be the most important factors influencing the total length during both sampling periods. A total of 23 different copepod species were identified during the survey period. The copepod abundance was higher in cold (74\%; 9.78

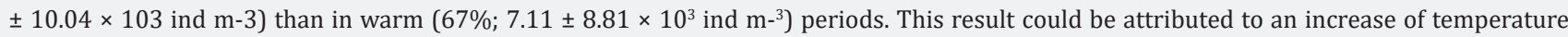
and salinity in August, which favors the development of smaller copepod species. During the cold season, larger adult broadcaster of calanoids species (total length between 0.98 and $1.22 \mathrm{~mm}$ ) such as Acartia (Acartia) danae (Giesbrecht) $(\mathrm{Tl}=1.22 \mathrm{~mm})$, Paracartia grani $(\mathrm{Sars})(\mathrm{Tl}=1.12$ $\mathrm{mm}$ ) and Paracartia latisetosa (Krichagin) $(\mathrm{Tl}=1.06 \mathrm{~mm})$ were associated to low temperature and salinity. During the warm period, smaller eggcarrying species of harpacticoids (total length between 0.18 and $0.3 \mathrm{~mm}$ ) such as Harpacticus littoralis (Sars), Tisbe furcata (Baird) and Tigriopus $s p$. (Norman) were associated with high temperature and heavy metal pollution. H. littoralis displayed a very high abundance of ovigerous females ( $\mathrm{Nfo}=12.8 \times 10^{3}$ ind $\mathrm{m}^{-3}$, representing $87.2 \%$ of total number of females) with high number of eggs per sac $\left(\mathrm{E}=26 \pm 2\right.$ egg sac- $\left.{ }^{1}\right)$.
\end{abstract}

Keywords: Southern coast of Sfax; Salinity; Total length; Heavy metals; Copepod; Warm and cold periods

\section{Introduction}

Most zooplankton organisms are very sensitive to physical, chemical and biological factors [1-4]. Their population dynamics in aquatic ecosystems is closely related to seasonal temperature variation [5-7]. Copepods are the most abundant zooplankton assemblages in marine ecosystems [8-10]. They play a pivotal role in aquatic food webs by transferring nutrient and energy from primary (e.g. phytoplankton) to tertiary (e.g. planktivorous fish) producers [11-15]. As they are highly dependent on environmental conditions (e.g. chemical and organic contaminants, temperature and salinity), copepod species have long been used as bioindicators of environmental quality and water mass origin $[16,17]$. Marine copepods can thus be an excellent tool for evaluating the impact of marine pollution throughout coastal regions because they quickly respond to different types of stress in different ways (e.g. decreased fecundity, mortality) [18-22].
The Southern coast of Sfax is a transitional system under high anthropogenic pressure [23-25]. Pollution by organic and chemical wastes in this area is mainly due to industrial and fishing activities [26]. Moreover, additional anthropogenic inputs of heavy metals in the Gulf of Gabes from the phosphogypsum waste released from the GCT-Gabes' and the SIAPE-Sfax phosphoric acid industrial complexes might be critical to the coastal marine ecosystems. This situation could lead to serious human health risks and chronic intoxication caused by their potential bioaccumulation in some aquatic fauna such as shrimp, fish, crab, shellfish, mollusk, copepods and cephalopods [27-34]. Several studies have already highlighted the importance of copepod assemblages as bioindicators of water quality changes in the coasts of Sfax $[35,36]$. Recent studies have evaluated the impact of pollutants on the survival, as well as genetic transcription and expression in several copepod species (Kmiha et al. submitted). In this work, we focused on the copepod community composition 
and on the morphology (total length) and reproduction traits (broadcasters, vs. sac spawners) in relation with temperature, salinity, and heavy metal concentration in two contrasting periods.

\section{Materials and Methods}

\section{Study Site}

The Southern coastline of Sfax is in the Southeast of Tunisia in the Northern part of the Gulf of Gabes (Southern Mediterranean Sea). Heavy metal inputs ( $\mathrm{Zn}, \mathrm{Ni}, \mathrm{Pb}, \mathrm{Co}, \mathrm{Cr}, \mathrm{Cd}, \mathrm{Mn}$ and $\mathrm{Cu}$ ) from the waste waters of more than 100 industrial plants including the phosphoric acid and fertilizer plant (SIAPE), the wastewater treatment station and the excessive marine traffic impacts this area.

\section{Sampling strategy and in situ measurements}

Eighteen stations were sampled in summer $\left(15^{\text {th }} 94\right.$ of August, from 12:15 p.m. to 7:30 p.m.) and winter (16 95 of January, from 8:30 a.m. to 1:30 p.m.) in 2013 (Figure 1). The depths of the stations varied from 3 to $6.2 \mathrm{~m}$ in August and from 4.2 and $7.4 \mathrm{~m}$ in January. At each station, salinity and temperature were measured using a multi-parameter kit (multi 340i/SET). Water transparency was determined with a Secchi disk. Seawater samples were taken at $\sim 0.1$-m depth using PVC
Van Dorn bottles (1.5 L) deployed horizontally to determine the suspended particulate matter (SPM), $\mathrm{pH}$, nutrients and chlorophyll-a. Samples for nutrient analyses $(120 \mathrm{~mL})$ were preserved immediately upon collection $\left(-20^{\circ} \mathrm{C}\right.$, in the dark). For heavy metal analyses, seawater samples were collected at $\sim 0.1$ m depth using $4 \mathrm{~L}$ Nalgene polycarbonate bottles. The bottles were opened below the water surface to avoid sampling of the surface microlayer. Before use, they were extensively washed with $1 \mathrm{M}$ hydrochloric acid $(\mathrm{HCl})$ and Milli- $\mathrm{Q}$ water, rinsed three times with the respective sample before filling. After collection, they were placed in cold and dark conditions. Zooplankton was collected using a cylindro conical net $(30 \mathrm{~cm}$ aperture, $100 \mathrm{~cm}$ height, $100 \mu \mathrm{m}$ mesh size) equipped with a Hydro-Bios flowmeter. In order to collect representative samples of the whole water column, the net was towed obliquely from near the bottom to the surface at a mean speed of $1 \mathrm{~m} \mathrm{~s}^{-1}$. The sample volume was calculated by multiplying the net aperture area $\left(0.071 \mathrm{~m}^{2}\right)$ by the distance travelled by the net (difference in flowmeter readings before and after sampling (using a conversion coefficient of 1.33). Zooplankton samples were rapidly preserved in a buffered formaldehyde solution (2\%). After then, they were stained with Rose Bengal to identify the internal tissues of the different zooplankton species and to facilitate copepod dissection.

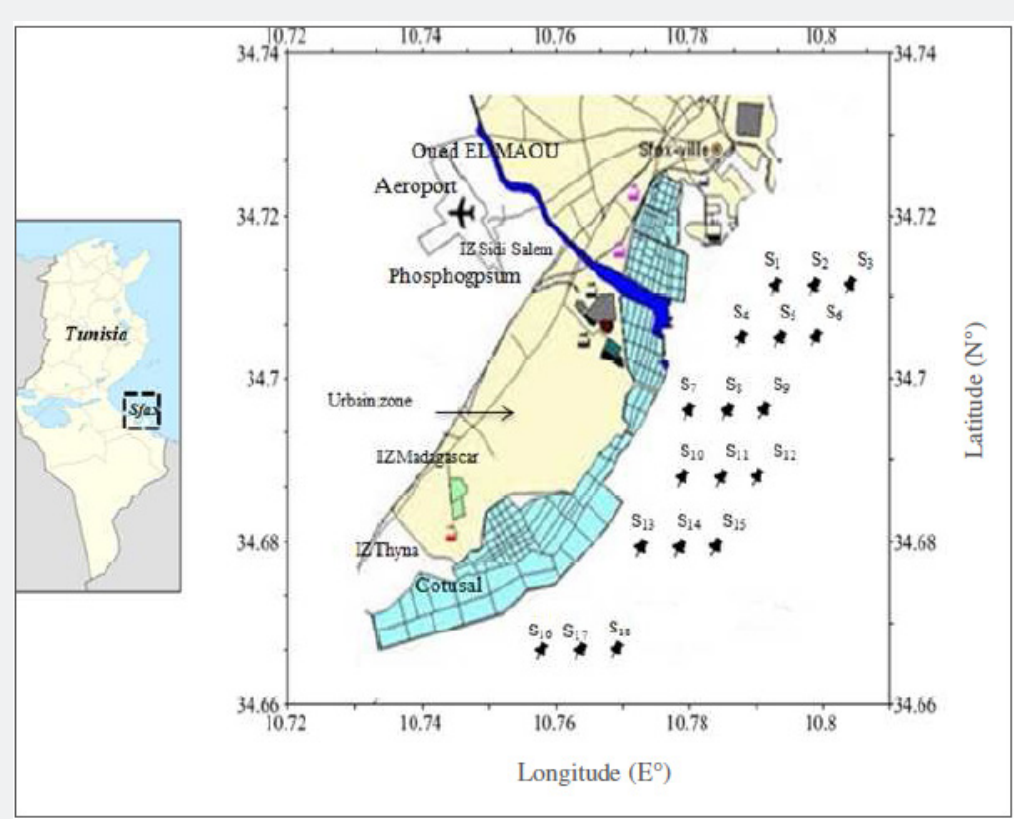

Figure 1: Zooplankton sampling stations in the southern coast of Sfax among season.

\section{Sample Analyses}

Nutrients $\left(\mathrm{NO}_{2}^{-}, \mathrm{NO}_{3}^{-}, \mathrm{NH}_{4}+, \mathrm{PO}_{4}^{3}-, \mathrm{Si}(\mathrm{OH})_{4}, \mathrm{~T}-\mathrm{N}\right.$ and T-P) were analyzed with a BRAN and LUEBBE type 3 auto-analyzer and their concentrations were determined calorimetrically using a UV-visible (6400/6405) spectrophotometer (APHA, 2012). We also calculated the N/P: DIN (DIN $=\mathrm{NO}_{2^{-}}+\mathrm{NO}_{3^{-}}+$ $\mathrm{NH}_{4}+$ ) to DIP (DIP = P043-) ratio. The SPM concentrations were determined by measuring the dry weight of the residue after filtration of $1 \mathrm{~L}$ of seawater onto Whatman GF/C filters. Chl-a analyses were carried out by spectrophotometry, after extraction of the pigments in $10 \mathrm{~mL}$ acetone (90\%) for $24 \mathrm{~h}$, in the dark at $4^{\circ} \mathrm{C}$ [37] and the concentrations then estimated using the SCOR-UNESCO (1966) equations. Trace metals, i.e. cadmium $(\mathrm{Cd})$, cobalt $(\mathrm{Co})$, chromium $(\mathrm{Cr})$, copper $(\mathrm{Cu})$, iron $(\mathrm{Fe})$, lead 
$\mathrm{Pb})$, manganese $(\mathrm{Mn})$, and zinc $(\mathrm{Zn})$ were analyzed by means of flame 125 atomic absorption spectrophotometry (AAS) (Perkin Elmer A-Analyst 200 instrument copyright @ 2007, version 6 model). Seawater samples were filtered under vacuum filtration using a $0.2 \mu \mathrm{m}$ filter and the liquid phase underwent acid attack.

Zooplankton samples were identified according to Rose [38], Bradford-Grieve [39] and Costanzon et al. [40] for copepods and according to Tregouboff \& Rose [41,42] for non-copepod zooplankton. The names of species were checked using WORMS (http://www.marinespecies.org/). The different copepod species were sorted into four stage development classes (nauplii, copepodids, adult males and adult females). For cyclopoids, poecilostomatoids and harpacticoids fecundity parameters (number of ovigerous females the number of ovigerous females $(N f o)$ and number of eggs per sac $(N)$ ), were estimated. Enumeration was performed under a vertically mounted deepfocus dissecting microscope (Olympus TL 2) and numerical density (individual $\mathrm{m}^{-3}$ ) was calculated using the sampling volume. Total length ( $\mathrm{Tl}$ in $\mathrm{mm}$ ) of adults of each species was also measured. Copepod dominance index $(\mathrm{Y})$ was calucalted using the following formula: $\mathrm{Y}=\frac{\mathrm{ni}}{\mathrm{N}} \times$ fi where $\mathrm{n}_{\mathrm{i}}$ is the number of individuals of species $i$ and $f i$ is the frequency of species $i$ occurring in a sample and $N$ is the total number of species. Species with a $Y$ value of more than or equal to $(20 \%)$ were defined as dominant species. Species diversity was assessed by using the Shannondiversity index $H^{\prime}$ (Shannon \& Weaver, 1949): $H^{\prime}=-\sum_{n i} \frac{n i}{N} \log _{2} \frac{n i}{N}$ where ni is the number in the sample. We also calculated the Pielou's evenness index $J^{\prime}=\frac{H^{\prime}}{H^{\prime} \max } \quad$ [43] and the Margalef species diversity index [44], $D M g=(S-1) / \log _{2} N$ where $\mathrm{N}$ is the total number of individuals and $\mathrm{S}$ is the number of species

\section{Data processing and statistical 148 analysis}

Correlations between the different biological and physicochemical parameters was tested using Pearson's rank correlation (XL-Stat software) and differences between the two sampling periods for the different parameters analyzed (ANOVA tests). Moreover, a canonical correspondence analysis (CCA) [45] was applied to explain the relationships between physical (temperature, salinity, turbidity, and $\mathrm{pH}$, biogeochemical (orthophosphate, $\mathrm{Zn}, \mathrm{Ni}, \mathrm{Pb}, \mathrm{Co}, \mathrm{Cr}, \mathrm{Cd}, \mathrm{Mn}$ and $\mathrm{Cu}$ and suspended particulate matter) and biological (chlorophyll-a; harpacticoids, calanoids, cyclopoids and dominant copepod species abundance and mean body length of adult copepods) parameters. Variables that did not reach the normality assumption were logarithmically transformed to ensure homogeneity of variance [46].

\section{Results}

Mean values \pm SD of the different physical (water temperature, salinity, $\mathrm{pH}$, and transparency), biogeochemical $\left(\mathrm{NO}_{3}{ }^{-}, \mathrm{NO}_{2}{ }^{-}, \mathrm{NH}_{4}{ }^{+}\right.$, $\mathrm{PO}_{4}{ }^{3-}$, T-N, T-P, N/P ratio, $\mathrm{Si}(\mathrm{OH})_{4}$ ), trace metals ( $\mathrm{SPM}, \mathrm{Zn}, \mathrm{Ni}, \mathrm{Pb}$, $\mathrm{Co}, \mathrm{Cr}, \mathrm{Cd}, \mathrm{Mn}$ and $\mathrm{Cu}$ ) and biological (Chl-a, copepod abundance, total length of copepod species and diversity index) parameters are summarized in Table1.

Table 1: Mean values ( \pm standard deviation, SD) of physical and biogeochemical parameters and of diversity indexes for copepods $\left(H^{\prime}\right.$ : Shannon and Wiener diversity index, $Y$ : dominance index, S: Species number and $D_{M q}$ : Margalef species diversity index) in the southern coast of Sfax among sampling periods (January-August 2013). In the last column are shown results of one-way ANOVA (F values and $p$ significance) to test differences between sampling periods. Significant degrees for $p$ are: ${ }^{*} p<0.05 ;{ }^{* *} p<0.001 ;{ }^{* * *} p<0.0001 ; n s=$ non-significant $(p>0.05)$

\begin{tabular}{|c|c|c|c|c|c|c|c|}
\hline Variables & \multicolumn{3}{|c|}{ January 2013} & \multicolumn{3}{|c|}{ August 2013} & \multirow{2}{*}{$\begin{array}{l}\text { ANOVA between } \\
\text { sampling (p } \\
\text { levels) }\end{array}$} \\
\hline Physical Parameters & Min & Max & Mean \pm SD & Min & Max & Mean \pm SD & \\
\hline Depth (m) & 4.2 & 7.4 & $5.84 \pm 1.15$ & 3 & 6.2 & $4.64 \pm 1.15$ & $* *$ \\
\hline Temperature $\left({ }^{\circ} \mathrm{C}\right)$ & 12.5 & 15 & $14.05 \pm 0.85$ & 23 & 25.5 & $24.54 \pm 0.89$ & $* * *$ \\
\hline Salinity (p s u) & 30 & 35 & $32.5 \pm 0.77$ & 32 & 42 & $39.38 \pm 2.03$ & $* * *$ \\
\hline pH & 7.1 & 8.2 & $7.66 \pm 0.32$ & 7.67 & 7.92 & $7.83 \pm 0.10$ & $* * *$ \\
\hline Transparency (m) & 0.8 & 4 & $2.40 \pm 1.16$ & 3.8 & 7 & $5.39 \pm 1.11$ & $* * *$ \\
\hline $\begin{array}{c}\text { Suspended } \\
\text { particulate matter } \\
\left(\mathrm{mg} \mathrm{L}^{-1}\right)\end{array}$ & 22 & 72 & $45.89 \pm 11.57$ & 51.2 & 87.2 & $64.51 \pm 11.02$ & $* * *$ \\
\hline \multicolumn{8}{|l|}{$\begin{array}{c}\text { Biogeochemical } \\
\text { parameters }\end{array}$} \\
\hline $\mathrm{NO}_{3}^{-}(\mu \mathrm{M})$ & 0.98 & 2.47 & $1.52 \pm 0.48$ & 1.31 & 6.05 & $2.93 \pm 1.19$ & $* * *$ \\
\hline $\mathrm{NO}_{2} \cdot(\mu \mathrm{M})$ & 0.097 & 0.4 & $0.22 \pm 0.07$ & 0.1 & 1.57 & $0.31 \pm 0.34$ & ns \\
\hline $\mathrm{NH}_{4}^{+}(\mu \mathrm{M})$ & 0.13 & 0.5 & $0.29 \pm 0.11$ & 0.7 & 12 & $3.15 \pm 2.80$ & $* * *$ \\
\hline $\mathrm{T}-\mathrm{N}(\mu \mathrm{M})$ & 10.02 & 19.99 & $16.86 \pm 2.86$ & 12.59 & 46.89 & $17.74 \pm 7.85$ & $* * *$ \\
\hline $\mathrm{PO4}_{3}-(\mu \mathrm{M})$ & 0.35 & 3.9 & $1.15 \pm 0.85$ & 1.44 & 14.14 & $3.30 \pm 3.21$ & $* * *$ \\
\hline T-P $(\mu \mathrm{M})$ & 1.52 & 5.18 & $3.40 \pm 1.21$ & 4.42 & 49.3 & $12.62 \pm 10.10$ & $* * *$ \\
\hline $\mathrm{Si}(\mathrm{OH})_{4}(\mu \mathrm{M})$ & 1.36 & 5.3 & $3.01 \pm 1.08$ & 11.12 & 113.13 & $22.50 \pm 23.37$ & $* * *$ \\
\hline $\mathrm{N} / \mathrm{P}$ ratio & 4.24 & 32.08 & $11.52 \pm 7.30$ & 0.68 & 7.33 & $2.99 \pm 2.11$ & $* * *$ \\
\hline Lead $(\mathrm{Pb})\left(\mu \mathrm{g} \mathrm{L}^{-1}\right)$ & 0 & 410 & $620 \pm 89$ & 1 & 561 & $750 \pm 120$ & $* *$ \\
\hline
\end{tabular}




\begin{tabular}{|c|c|c|c|c|c|c|c|}
\hline Iron $(\mathrm{Fe})\left(\mu \mathrm{g} \mathrm{L}^{-1}\right)$ & 80 & 330 & $210 \pm 71$ & 190 & 510 & $340 \pm 93$ & ** \\
\hline Copper $(\mathrm{Cu})\left(\mu \mathrm{g} \mathrm{L}^{-1}\right)$ & 6 & 62 & $30 \pm 15$ & 8 & 80 & $41 \pm 20$ & $*$ \\
\hline $\operatorname{Zinc}(\mathrm{Zn})\left(\mu \mathrm{g} \mathrm{L}^{-1}\right)$ & 0 & 150 & $54 \pm 22$ & 0 & 300 & $111 \pm 75$ & $* *$ \\
\hline $\begin{array}{c}\text { Manganese }(M n)(\mu g \\
\left.L^{-1}\right)\end{array}$ & 13 & 150 & $71 \pm 31$ & 35 & 180 & $109 \pm 51$ & ** \\
\hline$\underset{\left.L^{-1}\right)}{\operatorname{Cadmium}(C d)}(\mu \mathrm{g}$ & 10 & 35 & $24 \pm 8.4$ & 22 & 70 & $49 \pm 10$ & ** \\
\hline \multicolumn{8}{|l|}{ BiologicalParameters } \\
\hline $\begin{array}{c}\text { Chlorophyll-a } \\
\text { concentration }\left(\times 10^{3}\right. \\
\left.\mu \mathrm{g} \mathrm{L}^{-1}\right)\end{array}$ & 2.65 & 3.76 & 2.43 & 0 & 2.46 & $1.11 \pm 0.81$ & $* * *$ \\
\hline $\begin{array}{c}\text { Zooplankton } \\
\text { abundance }\left(\times 10^{3} \text { ind }\right. \\
\mathbf{m}^{-3)}\end{array}$ & 4.31 & 72.19 & $13.15 \pm 15.51$ & 1.93 & 18.56 & $10.31 \pm 16.35$ & ns \\
\hline \multicolumn{8}{|l|}{ Copepod abundance } \\
\hline$(\times 10$ ind $\mathrm{m})$ & 3.1 & 46.62 & $9.78 \pm 10.04$ & 1.51 & 12.81 & $7.11 \pm 8.81$ & ** \\
\hline \multicolumn{8}{|l|}{ Calanoids abundance } \\
\hline$(\times 10$ ind $m)$ & 0.26 & 13 & $2.39 \pm 2.93$ & 0.17 & 35.09 & $1.94 \pm 0.94$ & ns \\
\hline \multicolumn{8}{|l|}{$\begin{array}{l}\text { Cyclopoids } \\
\text { abundance }\end{array}$} \\
\hline$(\times 10$ ind $\mathrm{m})$ & 0.29 & 17.63 & $4.09 \pm 4.03$ & 0.09 & 30.75 & $1.70 \pm 1.55$ & ns \\
\hline $\begin{array}{c}\text { Harpacticoids } \\
\text { abundance }(\times 10 \text { ind } \\
\mathrm{m})\end{array}$ & 0.11 & 5.73 & $1.59 \pm 1.48$ & 0.25 & 41.97 & $2.3 \pm 3.47$ & $\mathrm{~ns}$ \\
\hline $\begin{array}{l}\text { Poecilostomatoids } \\
\text { abundance ( } \times 10 \text { ind } \\
\mathrm{m})\end{array}$ & 0.01 & 0.21 & $0.06 \pm 0.05$ & 0 & 0.44 & $0.02 \pm 0.03$ & $* * *$ \\
\hline $\begin{array}{l}\text { Other zooplankton } \\
\text { abundance ( } \times 10 \text { ind } \\
\mathrm{m})\end{array}$ & 0.53 & 25.57 & $3.36 \pm 5.62$ & 0.06 & 37.75 & $2.09 \pm 5.49$ & ns \\
\hline $\begin{array}{c}\text { Total length of all } \\
\text { copepod species } \\
(\mathrm{mm})\end{array}$ & 0.18 & 1.22 & $0.6 \pm 0.36$ & 0.22 & 1.11 & $0.59 \pm 0.28$ & $\mathrm{~ns}$ \\
\hline \multicolumn{8}{|l|}{ Diversity index } \\
\hline $\mathbf{Y}$ & 0.34 & 0.83 & $0.57 \pm 0.14$ & 0.19 & 0.94 & $0.54 \pm 0.14$ & $\mathrm{~ns}$ \\
\hline$S$ & 8 & 22 & $15 \pm 3.82$ & 18 & 23 & $20 \pm 2.28$ & $\mathrm{~ns}$ \\
\hline DMg & 1.28 & 3.79 & $4.11 \pm 0.94$ & 2.73 & 5.05 & $4.01 \pm 0.74$ & ns \\
\hline $\mathbf{H}^{\prime}$ & 1.02 & 2.64 & $1.75 \pm 0.51$ & 1.4 & 3.14 & $2.53 \pm 0.42$ & ** \\
\hline
\end{tabular}

\section{Physical and biogeochemical parameters}

Water temperature and salinity were significantly higher in August $\left(24.54 \pm 0.89{ }^{\circ} \mathrm{C} ; 39.38 \pm 2.03 \mathrm{psu}\right.$ ) than in January $\left(14.05 \pm 0.85^{\circ} \mathrm{C} ; 32.5 \pm 0.77 \mathrm{psu}\right)$. pH was significantly higher in August $(7.83 \pm 0.10$ ) (Table 1). All biogeochemical parameters displayed higher values in August than in January except for the SPM concentrations. These parameters displayed significant differences between the two periods, except for $\mathrm{NO}_{2}$.

\section{Biological parameters and 173 diversity indexes}

Chl-a concentration as well as abundances of copepods and poecilostomatoids were significantly higher in January than August $(\mathrm{p}<0.0001)$. Calanoids, harpacticoids and cyclopoids as well as total zooplankton did not vary significantly between the two periods. The copepod diversity indexes did not vary significantly between sampling periods ( $p>0.05$ ) except for the Shannon index which was significantly higher in August than January $(p<0.001)$. A total of 23 different copepod species were identified throughout the survey period; their abundance and their morphological (total length) and reproductive (broadcasters, sac spawners) traits varied between the cold and the warm periods (Table 2). The species richness ranged from 8 to 23 species per sample (mean $=15$ in January and 20 in August). Moreover, the copepod community was more diversified in August $\left(H^{\prime}=1.4-3.14\right.$ bits ind $\left.{ }^{-1}\right)$ than in January $\left(\mathrm{H}^{\prime}=1.02-2.64\right.$ bits ind $\left.^{-1}\right)(\mathrm{p}<0.001)$. 
Table 2: Taxonomic composition of the copepod community: mean values per season and per species of total length (TL mm); abundance $\left(A, \times 10^{3}\right.$ ind $\left.m^{-3}\right)$;

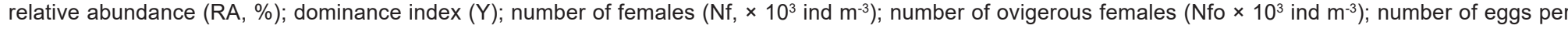
sac $(\mathrm{E})$; indication of the spawning mode: $\mathrm{S}=$ egg-carrier; B: broadcast spawners. ${ }^{*}=$ dominant species.

\begin{tabular}{|c|c|c|c|c|c|c|c|c|c|c|c|c|c|c|}
\hline \multirow[b]{2}{*}{ Order } & \multirow[b]{2}{*}{ Species } & \multicolumn{6}{|c|}{ Jan-13 } & \multicolumn{6}{|c|}{ Aug-13 } & \multirow{2}{*}{$\begin{array}{c}\text { Spawning } \\
\text { Mode }\end{array}$} \\
\hline & & $\begin{array}{c}\mathrm{TL} \\
(\mathrm{mm})\end{array}$ & A & $\begin{array}{l}\text { RA } \\
(\%)\end{array}$ & $\mathbf{Y}$ & Nf & NfoE & $\begin{array}{c}\mathrm{TL} \\
(\mathrm{mm})\end{array}$ & A & $\begin{array}{l}\text { RA } \\
(\%)\end{array}$ & $\mathbf{Y}$ & $\mathbf{N f}$ & NfoE & \\
\hline \multirow{10}{*}{$\begin{array}{c}\text { Calanoids } \\
(0.98-1.22 \mathrm{~mm})\end{array}$} & $\begin{array}{l}\text { Acartia (Acartia) } \\
\text { danae }\end{array}$ & 1.22 & 11.7 & 12.84 & 0.033 & 3.69 & & 1.11 & 3.16 & 1.73 & 0.011 & 2.11 & & B \\
\hline & (Giesbrecht,1889) * & & & & & & & & & & & & & \\
\hline & Paracartia grani & 1.12 & 9.57 & 11.18 & 0.051 & 1.57 & & 1.02 & 11.81 & 16.41 & 0.01 & 9.5 & & $\mathrm{~B}$ \\
\hline & (Sars GO, 1904) * & & & & & & & & & & & & & \\
\hline & $\begin{array}{l}\text { Paracartia latisetosa } \\
\text { (Krichagin, 1873) * }\end{array}$ & 1.06 & 2.21 & 10.47 & 0.025 & 1.85 & & 1.01 & 6.11 & 1.52 & 0 & 3.5 & & B \\
\hline & $\begin{array}{c}\text { Acartia (Acartiura) } \\
\text { longiremis } \\
\text { (Lilljeborg, 1853) }\end{array}$ & 1.05 & 0.37 & 6.2 & 0.001 & 0.12 & & 0.98 & 5.7 & 1.72 & 0.017 & 1.8 & & B \\
\hline & Acartia sp. & 1.03 & 0.27 & 5.2 & 0.042 & 0.11 & & 0.93 & 0.45 & 1 & 0.01 & 0.2 & & B \\
\hline & $\begin{array}{c}\text { Acartia (Acartiura) } \\
\text { clausi (Giesbrecht, } \\
1889 \text { ) }\end{array}$ & 1.02 & 4 & 3.74 & 0.012 & 2.45 & & 0.97 & 3.16 & 1.92 & 0.014 & 2.7 & & B \\
\hline & $\begin{array}{l}\text { Temora longicornis } \\
\text { (Müller OF, 1785) }\end{array}$ & 0.99 & 0.13 & 2.29 & 0.001 & 0.1 & & 0.81 & 1.2 & 1.11 & 0.01 & 0.98 & & S \\
\hline & $\begin{array}{l}\text { Paracalanus parvus } \\
\text { parvus (Claus, 1863) }\end{array}$ & 0.98 & 0.8 & 1.03 & 0.002 & 0.42 & & 0.76 & 0.65 & 0.6 & 0.006 & 0.12 & & $S$ \\
\hline \multirow{5}{*}{$\begin{array}{c}\text { Cyclopoids }(0.42- \\
0.6 \mathrm{~mm})\end{array}$} & $\begin{array}{c}\text { Oithona plumifera } \\
\text { plumifera (Baird, } \\
1843 \text { ) }\end{array}$ & 0.6 & 4 & 3.59 & 0.036 & 2.8 & 1.9616 & 0.62 & 2.17 & 2.21 & 0.012 & 1.4 & 1.216 & S \\
\hline & $\begin{array}{l}\text { Oithona setigera } \\
\text { (Dana, 1849) }\end{array}$ & 0.55 & 3.36 & 6 & 0.007 & 3.05 & 2.0113 & 0.45 & 1.99 & 1.15 & 0.017 & 1.02 & 0.9815 & S \\
\hline & Oithona sp. & 0.54 & 7 & 0.72 & 0.003 & 5.63 & 3.519 & 0.39 & 2.01 & 1.04 & 0.011 & 1.74 & 1.6620 & $S$ \\
\hline & $\begin{array}{c}\text { Oithona nana } \\
\text { (Giesbrecht, 1893) }\end{array}$ & 0.52 & 19.6 & 7.6 & 0.196 & 12.8 & 9.818 & 0.53 & 11.19 & 8.64 & 0.049 & 8.7 & 7.919 & $S$ \\
\hline & $\begin{array}{l}\text { Oithona similis } \\
\text { (Claus, 1866) }\end{array}$ & 0.51 & 22 & 8.11 & 0.268 & 18.21 & 13.516 & 0.49 & 10.61 & 7.04 & 0.039 & 7.8 & 6.318 & S \\
\hline \multirow{5}{*}{$\begin{array}{l}\text { Poecilostomatoids } \\
\text { (0.19-0.42 mm })\end{array}$} & $\begin{array}{l}\text { Corycaeus clausi } \\
\text { (Dahl F., 1894) }\end{array}$ & 0.42 & 1.23 & 0.16 & 0.02 & 0.08 & 0.036 & 0.43 & 0.1 & 0.77 & 0.009 & 0.003 & 05 & S \\
\hline & $\begin{array}{l}\text { Corycaeus specious } \\
\text { (Dana, 1849) }\end{array}$ & 0.41 & 0.23 & 0.11 & 0.01 & 0.52 & 0.017 & 0.42 & 0.03 & 0.51 & 0.013 & 0.01 & 0.016 & $S$ \\
\hline & $\begin{array}{c}\text { Triconia minuta } \\
\text { (Giesbrecht, 1893) }\end{array}$ & 0.32 & 1.03 & 0.33 & 0.01 & 0.2 & 0.108 & 0.33 & 0.05 & 0.26 & 0.011 & 0.01 & 0.015 & S \\
\hline & $\begin{array}{l}\text { Oncaea mediterranea } \\
\text { (Claus, 1863) }\end{array}$ & 0.19 & 0.07 & 0.11 & 0.01 & 0.1 & 0.084 & 0.29 & 0.11 & 0.23 & 0.014 & 0.44 & 0.216 & S \\
\hline & $\begin{array}{c}\text { Triconia conifera } \\
\text { (Giesbrecht, 1891) }\end{array}$ & 0.21 & 0.48 & 0.31 & 0 & 0.19 & 0.126 & 0.22 & 0.05 & 0.15 & 0.011 & 0.01 & 0.016 & $S$ \\
\hline \multirow{5}{*}{$\begin{array}{l}\text { Harpacticoids } \\
(0.18-0.3 \mathrm{~mm})\end{array}$} & $\begin{array}{l}\text { Harpacticus littoralis } \\
\text { (Sars G.O., 1910)* }\end{array}$ & 0.3 & 3.44 & 6.04 & 0.01 & 3.12 & 2.1010 & 0.5 & 15.35 & 29.02 & 0.026 & 14.5 & 12.826 & $S$ \\
\hline & $\begin{array}{l}\text { Tisbe furcata furcata } \\
\text { (Baird, 1837)* }\end{array}$ & 0.29 & 2.4 & 2.28 & 0.018 & 2 & 1.029 & 0.39 & 9.07 & 11.81 & 0.021 & 8.1 & 7.924 & S \\
\hline & $\begin{array}{c}\text { Tigriopus sp. } \\
\text { (Norman, 1869) * }\end{array}$ & 0.22 & 1.87 & 1.85 & 0.004 & 1.02 & 0.638 & 0.32 & 8.1 & 10.61 & 0.002 & 7.07 & 6.320 & $S$ \\
\hline & $\begin{array}{l}\text { Euterpina acutifrons } \\
\text { (Dana, 1847) }\end{array}$ & 0.21 & 4.86 & 9.3 & 0.084 & 3.85 & 3.0918 & 0.22 & 6.56 & 0.46 & 0.002 & 5.8 & 3.0119 & $S$ \\
\hline & $\begin{array}{c}\text { Clytemnestra } \\
\text { scutellata (Dana, } \\
\text { 1852) }\end{array}$ & 0.18 & 0.49 & 0.55 & 0.001 & 0.12 & 0.000 & 0.38 & 0.12 & 0.12 & 0.001 & 0.01 & 0.0110 & $S$ \\
\hline
\end{tabular}


August, small egg carrying harpacticoids (total length between 0.18 and $0.3 \mathrm{~mm}$ ) and more specifically Harpacticus littoralis (29.02\%), Tisbe furcata (11.81\%) and Tigriopus sp. (10.61\%) were the most abundant species. H. littoralis showed a very high abundance of ovigerous females $\left(N f o=12.8 \times 10^{3}\right.$ ind $\mathrm{m}^{-3}$, representing $87.2 \%$ of total female number) with the highest number of eggs per sac $\left(\mathrm{E}=26 \pm 2 \mathrm{egg} \mathrm{sac}^{-1}\right)$ compared to the other species (Table 2). However, in January, large broadcaster calanoids (total length between 0.98 and 1.22 mm) mainly Acartia (Acartia) danae (12.84\%), Paracartia grani
(11.18\%) and Paracartia latisetosa (10.74\%) were dominant. Other species as Euterpina acutifrons (Dana), a more ubiquitous harpacticoid, displayed no marked difference in fecundity parameters and prosome length between periods ( $p>0.05$ ). All calanoid species displayed a larger adult body size in January (0.98-1.22 mm) compared to August (0.76-1.11 mm) whereas poecilostomatoids $(\mathrm{p}<0.05)$ and harpacticoids ( $\mathrm{p}<0.001$ ) showed an opposite trend (0.19-0.42 and 0.18-0.3, in January and 0.22-0.43 and 0.22-050 mm in August).
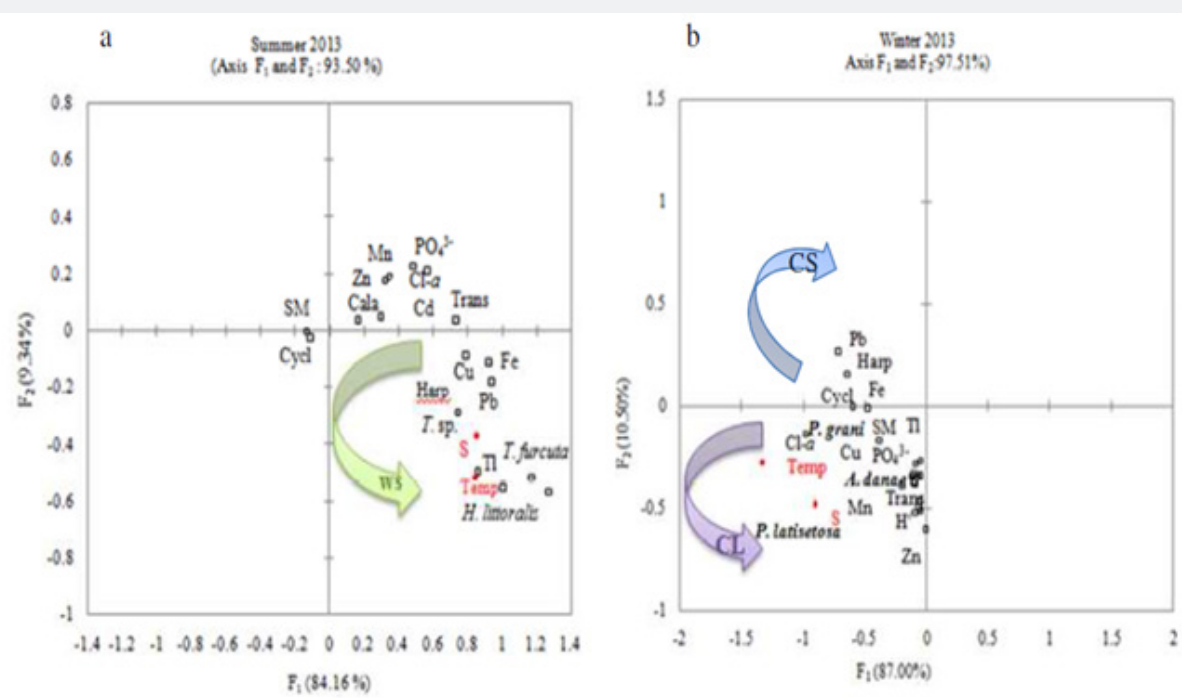

Figure 2: Canonical correspondence ordination (CCA) of the copepod species coupled with environmental parameters in the Southern coast of Sfax during warm (A) and cold (B) periods. Biplots of the species (frequency of occurrence $>71.43 \%$ ) and selected physical, biogeochemical and biological parameters. Tem: Water temperature $\left({ }^{\circ} \mathrm{C}\right)$; S: salinity (psu); SM: Suspended particulate matter (mg I-1); Tur: Turbiity (NTU); PO43- :Orthophosphate ( $\mu \mathrm{mol} \mathrm{I-1);} \mathrm{major} \mathrm{element:} \mathrm{Fe:} \mathrm{Iron} \mathrm{(} \mu \mathrm{g} \mathrm{I}-1)$ and Mn: Manganese $(\mu \mathrm{g} \mathrm{I}-1)$, trace metals: Zn:

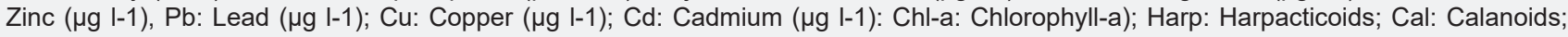
Cyc: Cyclopids; TI: Total length; cold-water small (CS); Cold-water large (CL): P. grani: Paracartia grani, A. danae: Acartia danae and P. latisetosa: Paracartia latisetosa (with reproduction mode: Broadcast spawner) and Warm-water small (WS): H. littoralis: Harpacticus littoralis; T. furca: Tisbe furca (with reproduction mode: Sac spawner)
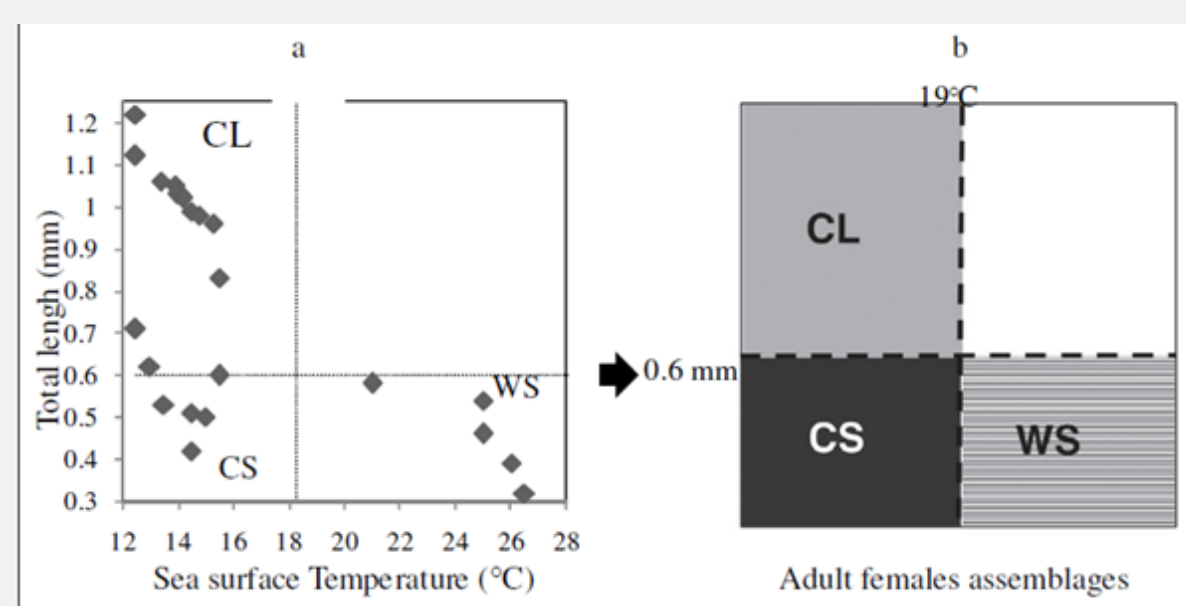

Figure 3: (A) Relationship of mean total length of adult females at the period of optimal abundance and corresponding surface seawater temperature (during August or January 2013) of the 23 copepod taxa. (B) Classification of copepod taxa based on the temperature and total length $(\mathrm{mm})$ criteria: cold-water large $(\mathrm{CL})$, cold-water small $(\mathrm{CS})$, and warm-water small $(\mathrm{WS})$ in the Southern coast of Sfax during August and January 2013. 


\section{Multivariate analysis}

In August 2013, the CCA allowed the discrimination of two groups around the F1 and F2 axes explaining 93.50\% of the variance (Figure 2). The first axis F1 (84.16\%) selected positively egg-carrying copepod species such as H. littoralis, $T$. furcata and Tigriopus sp. associated to high values of total length, temperature, salinity, $\mathrm{Cu}, \mathrm{Pb}$ and $\mathrm{Fe}$. This group was opposed to cyclopoids and calanoids associated to SPM, Zn and Mn. In January, abundances of almost all copepod species and groups were correlated to temperature, salinity and chl-a (Figure 2). On the second axis, larger species such as $A$. danae, $P$. grani and $P$. latisetosa were associated with temperature, salinity and heavy $\mathrm{Cu}, \mathrm{Mn}$ and $\mathrm{Zn}$ concentrations. This group was opposed to small cyclopoids and harpacticoids which were associated with $\mathrm{pH}$ and $\mathrm{Pb}$ concentration. Besides, H. littoralis was positively correlated with water temperature $(r=0.50$ cold-water large (CL: size $>0.6$ $\mathrm{mm}$, temperature $<19^{\circ} \mathrm{C}$ ), cold-water small (CS: size $<0.6 \mathrm{~mm}$, temperature $<19^{\circ} \mathrm{C}$ ) and warm-water small (WS: size $<0.6 \mathrm{~mm}$, sea surface temperature $>19^{\circ} \mathrm{C}$ ) copepod species (Figure 3).

\section{Multivariate analysis}

In August 2013, the CCA allowed the discrimination of two groups around the F1 and F2 axes explaining $93.50 \%$ of the variance (Figure 2). The first axis F1 (84.16\%) selected positively egg-carrying copepod species such as H. littoralis, $T$. furcata and Tigriopus sp. associated to high values of total length, temperature, salinity, $\mathrm{Cu}, \mathrm{Pb}$ and $\mathrm{Fe}$. This group was opposed to cyclopoids and calanoids associated to SPM, Zn and Mn. In January, abundances of almost all copepod species and groups were correlated to temperature, salinity and chl-a (Figure 2). On the second axis, larger species such as $A$. danae, $P$. grani and $P$. latisetosa were associated with temperature, salinity and heavy $\mathrm{Cu}, \mathrm{Mn}$ and $\mathrm{Zn}$ concentrations. This group was opposed to small cyclopoids and harpacticoids which were associated with $\mathrm{pH}$ and $\mathrm{Pb}$ concentration. Besides, H. littoralis was positively correlated with water temperature $(\mathrm{r}=0.50$ cold-water large (CL: size $>0.6$ $\mathrm{mm}$, temperature $<19^{\circ} \mathrm{C}$ ), cold-water small (CS: size $<0.6 \mathrm{~mm}$, temperature $<19^{\circ} \mathrm{C}$ ) and warm-water small (WS: size $<0.6 \mathrm{~mm}$, sea surface temperature $>19^{\circ} \mathrm{C}$ ) copepod species (Figure 3).

\section{Discussion}

In the present study, we focused on the variability of copepod assemblages in relation to physical and biogeochemical parameters in the Southern coast of Sfax in January and August 2013. The lowest pH values (7.1 in January and 7.67 in August, below the current seawater value 8) may reflect the influence of the SIAPE industrial effluent released in seawater. Indeed, it has been shown that this effluent was strongly acidic $(\mathrm{pH}=1.54)$ (Masri, 2005; Drira et al., 2016). The highest P043- concentration $(14.14 \mu \mathrm{M})$ was observed in August at station 7 located in front of the SIAPE manufactory, which may be related to release through of phosphogypsum wastes. In August, the mean value of P043- concentration $(3.3 \pm 3.21 \mu \mathrm{M})$ was in the range of values previously reported by Baccar [47] in the Gabes area (3.73 \pm $1.57 \mu \mathrm{M})$. The highest levels of P043- were always found near the potential sources, i.e. the SIAPE and wadi El Maou. Previous studies have shown high heavy metal concentrations in the sediment close to the GCT-Gabes' and the SIAPE-Sfax phosphoric acid industrial complexes $[48,49]$.

Our results showed higher amounts of $\mathrm{Zn}, \mathrm{Cd}, \mathrm{Mn}, \mathrm{Cr}$ and $\mathrm{Pb}$ in August than January 2013. The SIAPE plant is a source of high amounts of heavy metals (e.g. $\mathrm{Cd}, \mathrm{Zn}, \mathrm{Cu}, \mathrm{Co}, \mathrm{Ni}$ and $\mathrm{Pb}$ ). Drira et al., [25] reported mean concentrations of metals analyzed in the surface water of 26-77, 9-236, 217-318, 0-310, 446-919, 383-1015 $\mu \mathrm{g} \mathrm{l-1}$ for $\mathrm{Cd}, \mathrm{Zn}, \mathrm{Cu}, \mathrm{Co}, \mathrm{Ni}$ and $\mathrm{Pb} \mu \mathrm{g} \mathrm{l}-1$ respectively. However, industrial activities mainly tanneries and paper industry located near the coast are responsible for heavy metal pollution i.e. Cr (500 $\mu \mathrm{g} \mathrm{l-1)}$ and $\mathrm{Hg}(1 \mu \mathrm{g} \mathrm{l}-1)$, respectively [50]. Another source of trace metal pollution in this area is the fishing harbour (primarily $\mathrm{Cd}, \mathrm{Mn}$ and $\mathrm{Pb}$ which represented 5, 1000 and $500 \mu \mathrm{g}$ l-1, respectively). All analyzed metals (except for Fe and $\mathrm{Mn}$ ) are considered as moderate to extreme pollutants [51]. In the southern region of the Gulf of Gabes the major factor behind this pollution by heavy metals is phosphogypsum wastes, as shown in several previous works $[48,49,52]$.

In this study, we found that copepod was the dominant group representing 67 to $74 \%$ of total zooplankton. Similar values were previously reported in the Gulf of Gabes (20052007; 69-83\%; [53,54] and in the Southern coast of Sfax (2008; $66 \%)$. The copepod community was more diversified in August $\left(H^{\prime}=1.4-3.14\right.$ bits ind $\left.^{-1}\right)$ than in January $\left(H^{\prime}=1.02-2.64\right.$ bits ind- ${ }^{1}$ ), contrarily to results reported by Daly-Yahia et al. [55] in the Bay of Tunis (using the same copepod taxa level) with the highest diversity index in January (up to 3.83 bits ind-1), and the lowest in August (down to 0.24 bits ind- $^{-1}$ ). Similarly, SiokouFrangou [56] showed that in the Saronikos Gulf (Ionian Sea), the maximum diversity index (calculated for the whole zooplankton) was observed in January while the minimum values occurred in August. The copepod abundance was higher in cold (74\%; 9.78 $\pm 10.04 \times 103$ ind $\left.\mathrm{m}^{-3}\right)$ than in warm $\left(67 \% ; 7.11 \pm 8.81 \times 10^{3}\right.$ ind $\mathrm{m}^{-3}$ ) period.

Salinity and temperature have been found to control many copepod species distributions in marine coastal ecosystems [57-59]. It is well established that temperature is an important controlling factor for the biological cycles of copepod species $[60,61]$. In the present study, mean temperature values varied from $14.05 \pm 0.85^{\circ} \mathrm{C}$ in January to $24.54 \pm 0.89^{\circ} \mathrm{C}$ in August, in agreement with previous observations in the Gulf of Gabes $\left(23.07 \pm 2.47^{\circ} \mathrm{C}\right.$ in summer; [62] and in the Southern coast of Sfax $\left(15.33 \pm 0.64^{\circ} \mathrm{C}\right.$ in winter). This highwater temperature in August induced a decrease in total copepod abundance but an important increase of the percentage of harpacticoids (39\% of total copepod abundance; $r=0.542, p<0.05$ ). Positive effects of temperature on harpacticoid abundance were shown in laboratory conditions, in which the highest density was recorded 
at an optimum of $28^{\circ} \mathrm{C}$ [63] as well as in Mediterranean aquatic environments such as in Nasser lake (Egypt) [64] and the Sicily Channel (Central Mediterranean) [65]. In other Mediterranean regions, in agreement with our study, temperature was negatively correlated with copepod density [66]. Our results are also congruent with other previous studies which demonstrated that temperature strongly affects the copepod body length [67-69] through effects on their productivity, growth and development time [70-72].

In this study, the high abundance of large calanoid copepods ( $\mathrm{CL}=$ cold-water large copepods; $<19^{\circ} \mathrm{C}$ ) in January may be linked to their good adaptation to cold conditions. Besides the larger adult body size of these calanoids in January compared to August may result from a longer development times and correlative lower growth rates in cold condition as currently observed for calanoids $[73,74]$. However, the small harpacticoid copepods were more abundant (WS warm water short copepods; $>19^{\circ} \mathrm{C}$ ) and displayed higher adult body size during August Increase in adult body size of harpacticoid in August may be linked to a salinity effect as observed by Miliou [75] for Tisbe holothuriae. Besides, in August abundance of small egg carrying species such as H. littoralis $(\mathrm{Tl}=0.5 \mathrm{~mm})$, T. furcata $(\mathrm{Tl}=0.39 \mathrm{~mm})$ and Tigriopus sp. $(\mathrm{Tl}=0.32 \mathrm{~mm})$ also suggests that these species are favoured by the warm temperature conditions at this period (23-25 ${ }^{\circ} \mathrm{C}$ ). Tigriopus sp. is characterized by its high resistance to changes in temperature and environmental disturbances [7679]. In January, high abundance of large broadcaster species such as A. danae $(\mathrm{Tl}=1.22 \mathrm{~mm} \mathrm{12 \% )}$, $P$ grani $(\mathrm{Tl}=1.12 \mathrm{~mm}, 11.8 \%)$ and $P$. latisetosa $(\mathrm{Tl}=1.06 \mathrm{~mm}, 10.47 \%)$ were associated to low temperature $\left(12.5-15^{\circ} \mathrm{C}\right)$ and salinity $(30-35$ psu). Besides, species of the genus Acartia frequently dominate the pelagic environment of costal marine waters [80-82].

Salinity may have also impacted the observed copepod distribution. Indeed, large costal species (i.e. A. danae, P. grani and $A$. latisetosa) had their highest abundance at the lowest salinities in the cold season whereas, small copepods $(H$. littoralis T. furcata and Tigriopus $s p$.) dominated at highest salinities in August. In January, due to increased rainfall and continental water runoff, in such an ultra-coastal zone, salinity drops down to very low values $(S<35)$. Such condition may have favored the more euryhaline species and Acartidae known to be well adapted to salinity variations (e.g $[83,84]$ for $A$. clausi and A. tonsa respectively; [85] for A. longiremis). Finally, in addition to temperature and salinity effects, changes in food availability (namely biomass of phytoplankton) and pollution levels may also explain seasonal differences in copepod abundance and community composition. Indeed, lower copepod abundance, as well as higher percentage of small egg-carrying copepods in August, were related to the decrease of phytoplankton biomass (Chl-a concentration) and increase of heavy metal contamination Dependence of these omnivorous copepods (namely calanoid species) to phytoplankton abundance is well documented [86], whereas harpacticoids are less phytoplankton-dependant [87].

In January, high relative abundance of harpacticoids (in situation of low phytoplankton abundance) could have been linked to their wide prey composition. In fact, harpacticoids have been shown to manage to feed on detritus [88] as well as on microalgae [89-91]. It is known that heavy metals have potential negative effects on the hatching success of copepods [92]. Therefore, contamination by heavy metal could inhibit recruitment of nauplii, leading to decrease of copepod abundance. The reproductive success of copepods is vulnerable to contamination through all stages of their life cycle [93]. However, copepod resting eggs are much more sensitive to metals than adult copepod. In that case, it is important to consider the frequently ignored effect of these metals on the viability of some copepod species [92] since copepods are characterized by a great accumulation of metals [94]. Other impacts of heavy metal contamination on copepods have also been documented.

For example, damage effects (oxidative stress) of trace metals (as Cd or Ni) have been demonstrated on calanoid (870 and 12310 $\mu \mathrm{g} \mathrm{l}^{-1}$; for Cd and Ni, respectively; [95]) or harpacticoid (100 $\mu \mathrm{g}$ $\mathrm{l}^{-1}$ for $\mathrm{Cd}$; [96]) copepods. However, harpacticoids have been shown to be less sensitive to metal contamination, compared to other contaminants as endocrine disrupting chemicals and biocides [97]. This lower sensitivity to metal contamination may partly explain the higher relative abundance of harpacticoid in August when metal contamination was high. On another hand Acartidae have been shown to strongly decrease their reproduction rates when exposed to metal concentration which exceeded the permissible limits in coastal waters [98], which could explain their rarefaction in August in the southern coast of Sfax [99-104].

\section{Conclusion}

The present study revealed that copepods are vulnerable to temperature, salinity and heavy metal pollution. In fact, smallsized harpacticoid species are more abundant in the warm season, i.e. H. littoralis T. furcata and Tigriopus sp. coupled with high salinity, temperature and high metal concentration. During the cold season, larger adult broadcaster species of calanoids such as Acartia (Acartia) danae, Paracartia grani and Paracartia latisetosa were associated with low temperature, salinity and low heavy metal pollution levels. These findings support the assessment of the ecological effects on marine copepods in environments polluted by heavy metals. More toxicity studies at the population level should be performed to provide a comprehensive overview on how copepod populations respond to heavy metal pollution Some heavy metals analyzed in the present study are required as a chemical marker under a future project of monitoring and management programs, for reliable estimates of water quality. 


\section{Acknowledgment}

This work conducted in the Biodiversity and Aquatic Ecosystems UR11/ES72 Research Unit of the Sfax University was supported by the SEACNVS "Sociéte d'Etudes et d'Amenagement des Côtes Nord de la ville de Sfax: Taparura project" and SMAP III "Sfax Integrated Coastal Area Management" projects. It is a part of the PhD thesis of Salma KMIHA-MEGDICHE. The authors also express their sincere gratitude to Pr. Kamel MAALOUL from the English Language Unit at the Sfax Faculty of Science for his valuable help with the proofreading and language polishing of the manuscript.

\section{References}

1. Uriarte I, Villate F (2004) Effects of pollution on zooplankton abundance and distribution in two estuaries of the Basque coast (Bay of Biscay). Marine Pollution Bulletin 49: 220-228.

2. Hafferssas A, Seridji R (2010) Relationships between the hydrodynamics and changes in copepod structure on the Algerian coast. Zoological studies 49: 353-366.

3. Drira Z, Kmiha-Megdiche S, Sahnoun H, Pagano M, Tedetti M, et al. (2017a) Water quality affects the structure of copepod assemblages in the Sfax Southern coast (Tunisia, Southern Mediterranean Sea). Marine and Freshwater Research 69: 220-231.

4. Drira Z, Kmiha-Megdiche S, Sahnoun H, Tedetti M, Pagano M, et al. (2017b) Copepod assemblages as a bioindicator of environmental quality in three coastal areas under contrasted anthropogenic inputs (Gulf of Gabes, Tunisia). Journal of The Marine Biological Association of The United Kingdom 1-17.

5. Yoshida H, Compton J, Punnett S, Lovell T, Draper K, et al. (2010) Cetacean sightings in the eastern Caribbean and adjacent waters, Spring 2004. Aquatic Mammals 36: 154-161.

6. Sommer U, Adrian R, Domis LD, Elser JJ, Gaedke U, et al. (2012) Beyond the Plankton Ecology Group (PEG) Model: Mechanisms Driving Plankton Succession. In: DJ Futuyma (Ed) Annual Review of Ecology, Evolution, and Systematics, Palo Alto university, California, USA, pp. 429-448.

7. Bhattacharya BD, Bhattacharya A, Rakshit D, Sarkar SK (2014) Impact of the tropical cyclonic storm 'Aila' on the water quality characteristics and mesozooplankton community structure of Sundarban mangrove wetland. Indian Journal of Geo-MarineSciences 43: 216-223.

8. Tseng LC, Dahms HU, Chen QC, Hwang JS (2013) Geospatial variability of autumn community structure on epipelagic zooplankton in the upper layer of the northern South China Sea. Zoological studies 52: $1-22$.

9. Zheng Z (1989) Marine planktology. In: China Ocean Press, Beijing, China.

10. Uye S, Nagano N, Tamaki $T$ (1996) Geographical and seasonal variations in abundance, biomass and estimated production rates of microzooplankton in the Inland Sea of Japan. Journal of Oceanography 52: 689-703.

11. Kâ S, Hwang JS (2011) Mesozooplankton distribution and composition on the northeastern coast of Taiwan during autumn: effects of the Kuroshio Current and hydrothermal vents. Zoological studies 50: 155-163.

12. Yasuhara M, Hunt G, Dowsett HJ, Robinson MM, Stoll DK (2012) Latitudinal species diversity gradient of marine zooplankton for the last three million years. Ecology Letters 15: 1174-1179.
13. Pepin P, Catherine L, Johnson MH, Casault J, Chasse Eugene B, et al. (2015) A multivariate evaluation of environmental effects on zooplankton community structure in the western North Atlantic. Progress in Oceanography 134: 197-220.

14. Erondu CJ, Solomon RJ (2017) Identification of Planktons (Zooplankton and Phytoplankton) behind Girls' Hostel University of Abuja, Nigeria. Direct Research Journal of Public Health and Environmental Technology 2: 21-29.

15. Nakajima R, Yamazaki H, Lewis LS, Khen A, Smith JE, Nakatomi N Kurihara H (2017) Planktonic trophic structure in a coral reef ecosystem - Grazing versus microbial food webs and the production of mesozooplankton. Progress in Oceanography 156: 104-120.

16. Richardson AJ (2008) In hot water: zooplankton and climate change. ICES Journal of Marine Science 65: 279-295.

17. Hwang JS, Souissi S, Dahms HU, Tseng LC, Schmitt FG, et al. (2009) Rank-abundance allocations as a tool to analyze planktonic copepod assemblages off the Danshuei river estuary (Northern Taiwan). Zoological studies 48: 49-62.

18. Kusk KO, Wollenberge L (2007) Towards an internationally harmonized test method for reproductive and developmental effects of endocrine disrupters in marine copepods. Ecotoxicology 16: 183195.

19. Raisuddin S, Kwok KWH, Leung KMY, Schlenk D, Lee JS (2007) The copepod Tigriopus: a promising marine model organism for ecotoxicology and environmental genomics. Aquatic Toxicology 83: 161-173.

20. Daufresne M, Lengfellner K, Sommer U (2009) Global warming benefits the small in aquatic ecosystems. Proceedings of the National Academy of Sciences of the United States of America 106: 1278812793.

21. Murphy EJ, Hofmann EE, Watkins JL, Johnston NM, Piñones A, et al (2013) Comparison of the structure and function of Southern Ocean regional ecosystems: The Antarctic Peninsula and South Georgia. Journal of Marine Systems 109-110: 22-42.

22. Darnis G, Fortier L (2014) Temperature, food and the seasonal vertical migration of key arctic copepods in the thermally stratified Amundsen Gulf (Beaufort Sea, Arctic Ocean). Journal of Plankton Research 36: 1092-1108.

23. Serbaji MM, Azri C, Medhioub K (2012) Anthropogenic contributions to heavy metal distributions in the surface and sub-surface sediments of the Northern Coast of Sfax. International Journal of Environmental Research 6: 1735-6865.

24. Zaghden H, Kallel M, Elleuch B, Oudot J, Saliot A, (2014) Evaluation of hydrocarbon pollution in marine sediments of Sfax coastal areas from the Gabes Gulf of Tunisia, Mediterranean Sea. Environmental Earth Sciences 72: 1073-1082.

25. Drira Z, Sahnoun H, Ayadi H (2017c) Spatial distribution and source identification of heavy metals in surface waters of three coastal areas (Gulf of Gabes, Tunisia). Polish Journal of Environmental Studies 26: 1057-1069.

26. Ben Salem Z, Ayadi H (2016) Heavy metal accumulation in Diplodus annularis, Lizaaurata, and Solea vulgaris relevant to their concentration in water and sediment from the southwestern Mediterranean (coast of Sfax). Environmental Science and Pollution Research 23(14): 13895-13906.

27. Hamza-Chaffai A, Cosson RP, Amiard-Triquet C, El Abed A (1995) Physico chemical forms of storage of metals ( $\mathrm{Cd}, \mathrm{Cu}$ and $\mathrm{Zn}$ ) and metallothionein-like proteins in gills and liver of marine fish from the Tunisian coast: Ecotoxicological consequences. Comparative Biochemistry and Physiology Part C: Pharmacology, Toxicology and Endocrinology 111: 329-341. 
28. Hamza-Chaffai A, Pellerin J, Amiard JC (2003) Health assessment of a marine bivalve Ruditapes decussatus from the Gulf of Gabes (Tunisia). Environment International 28: 609-617.

29. Hamza-Chaffai A, Roméo M, El Abed A (1996) Heavy metals in different fishes from the middle eastern of Tunisia. Bulletin of Environmental Contamination and Toxicology 56: 766-773.

30. Zhou F, Guo H, Hao Z (2007) Spatial distribution of heavy metals in Hong Kong's marine sediments and their human impacts: A GIS based chemometric approach. Marine Pollution Bulletin 54: 13721384.

31. Jakimska A, Konieczka P, Skóra K, Namieśnik J (2011) Bioaccumulation of metals in tissues of marine animals, Part II: Metal concentrations in animal tissues. Polish Journal of Environmental Studies 20: 11271146.

32. Ahmad AK, Al Mahaqeri SA (2015) Human health risk assessment of heavy metals in fish species collected from catchments of former tin mining. International Journal of Research Studies in Science. Engineering and Technology 2: 9-21.

33. Ben Salem Z, Drira Z, Ayadi H (2015) What factors drive the variations of phytoplankton, ciliate and mesozooplankton communities in the polluted southern coast of Sfax, Tunisia? Environmental Science and Pollution Research 22: 11764-11780.

34. Zhuang W, Gao X (2016) Integrated assessment of heavy metal pollution in the surface sediments of the Laizhou bay and the coastal waters of the Zhangzi Island, China: Comparison among typical marine sediment quality indices. Polish Journal of Environmental Studies 9: 1-17.

35. Rekik A, Denis M, Aleya L, Maalej S, Ayadi H (2013) Spring plankton community structure and distribution in the north and south coasts of Sfax (Tunisia) after north coast restoration. Marine Pollution Bulletin 67: 82-93.

36. Rekik A, Denis M, Maalej S, Ayadi H (2015) Spatial and seasonal variability of pico nano and microphytoplankton at the bottom seawater in the north coast of Sfax, Eastern Mediterranean Sea. Environmental Science and Pollution Research 22: 15961-15975.

37. Lorenzen CJ (1967) Determination of chlorophyll and pheopigments: spectrophotometric equations. Limnology and Oceanography 16 : 990-992.

38. Rose M (1933) Faune de la France, Copépodes pélagiques. In: ScorUnesco, Paris, France, pp. 368.

39. Bradford-Grieve JM (1999) Copepoda. Sub-Order: Calanoida, Family: Acartiidae, 398 Genera: Acartia, Paracartia, Pteriacartia. In ICES Identification Leaflets for Plankton, Copenhagen K, Denmark, Europe.

40. Costanzo G, Campolmi M, Zagani G (2000) Stephos marsalensis 421 new species (Copepoda, Calanoida, Stephidae) from coastal waters of Sicily, Italy. Journal of Plankton Research 22: 2007-2014.

41. Tregouboff G, Rose M (1978a) Manuel de Planctologie Méditerranéenne. In: CNRS, Tome I, Paris, France.

42. Tregouboff G, Rose M (1978b) Manuel de Planctonologie Méditerranéenne, In: CNRS, Tome II, Paris, France.

43. Tramer EJ (1969) Bird species diversity: Components of Shannon's formula. Ecology 50: 927-929.

44. Warwick RM, Clarke KR (1995) New 'biodiversity' measures reveal a decrease in taxonomic distinctness with increasing stress. Marine Ecology Progress Series 129: 301-305.

45. Ter-Braak CJF (1986) Canonical correspondence analysis: A new eigenvector technique for multivariate direct gradient analysis

\section{Ecology 67: 1167-1179.}

46. Sokal RR, Rohlf FJ (1981) Biometry: the principles and practices of statistics in biological research. In: $\left(2^{\text {nd }}\right.$ ed.) Freeman and Company WH, New York

47. Baccar A (2014) Contribution à l'étude écologique du zooplancton de la côte du golfe de Gabès. Mastère, Université de Gabès, Faculté des Sciences de Gabès, Tunisie.

48. Illou S (1999) Impact des rejets telluriques d'origines domestiques et industrielles sur l'environnement côtier : cas de littoral de la ville de Sfax. Thèse de doctorat, Université de Tunis.

49. Ayadi N, Aloulou F, Bouzid J (2015) Assessment of contaminated sediment by phosphate fertilizer industrial waste using pollution indices and statistical techniques in the Gulf of Gabes (Tunisia). Arabic Journal of Geoscience 8(3): 1755-1767.

50. Pergent G, Kempf M (1993) L'environnement marin côtier en Tunisie. Rapport 539.

51. Ghannem N, Azri C, Serbaji MM, Yaich C (2011) Spatial Distribution of Heavy Metals in the Coastal Zone of "Sfax-Kerkennah" Plateau, Tunisia. Environmental Progress and Sustainable Energy 30(2): 221233.

52. Lahbib Y, Mleiki A, Trigui-El Menif N (2016) Bioaccumulation of trace metals in Hexaplex trunculus: spatial and trend temporal trends from 2004 to 2011 along the Tunisian coast. Environmental Science of Pollution Research 23: 16259-16271.

53. Drira Z, Hamza A, Bel Hassen M, Ayadi H, Bouain A et al. (2010) Coupling of phytoplankton community structure to nutrients, ciliates and copepods in the Gulf of Gabes south Ionian Sea, Tunisia). Journal of the Marine Biological Association of the United Kingdom 90: 12031215.

54. Drira Z, Bel Hassen M, Ayadi H, Aleya L (2014) What factors drive copepod community dynamics in the Gulf of Gabes, Eastern Mediterranean Sea? Environmental Science and Pollution Research 21: 2918-2934

55. Daly-Yahia MN, Souissi OS, Daly-Yahia-Kefi O (2004) Spatial and temporal structure of planktonic copepods in the Bay of Tunis (Southwestern Mediterranean Sea). Zoological Studies 43: 366-375.

56. Siokou-Frangou I (1996) Zooplankton annual cycle in a Mediterranean coastal area. Journal of Plankton Research 18 203-223.

57. Smith VH (2006) Responses of estuarine and coastal marine phytoplankton to nitrogen and phosphorus enrichment. Limnology and Oceanography 51: 377-384.

58. Smitha PG, Byrappa K, Ramaswamy SN (2007) Physico-chemical characteristics of water samples of Bantwal Taluk, South-Eastern Karnataka. Journal of Environmental Biology 28: 591-595.

59. Prabhahar C, Saleshrani K, Enbarasan R (2011) Studies on the ecology and distribution of phytoplankton biomass in Kadalur coastal zone Tamil Nadu, India. Current Botany 2: 26-30.

60. Gaudy R (1972) Contribution à la connaissance du cycle biologique des 470 copépodes du Golfe de Marseille. Etude du cycle biologique de quelques espèces caractéristiques. Tehtys 4: 175-242.

61. Hsiao SH, Fang TH, Shih CT, Hwang JS (2011) Effects of the Kuroshio Current on copepod assemblages in Taiwan. Zoological studies 50: 475-490.

62. Drira Z, Bel Hassen M, Hamza A, Rebai A, Bouain A, et al. (2009] Spatial and temporal variations of microphytoplankton composition related to hydrographic conditions in the Gulf of Gabes. Journal of the Marine Biological Association of the United Kingdom 89: 1559-1569. 
63. Rhyne AL, Ohs CL, Stenn E (2009) Effects of temperature on reproduction and survival of the calanoida copepod Pseudodiaptomus pelagicus. Aquaculture 292: 53-59.

64. Mageed AA, Heikal MT (2006) Factors affecting seasonal patterns in eplilimnion zooplankton community in one of the largest man-made lakes in Africa (Lake Nasser, Egypt). Limnologica 36: 91-97.

65. Brugnano C, Bergamasco A, Granata A, Guglielmo L, Zagami G (2010) Spatial distribution and community structure of copepods in a central Mediterranean key region (Egadi Islands-Sicily Channel). Journal of marine systems 81: 312-322.

66. Fernandez de Puelles ML, Alemany F, Jansá J (2007) Zooplankton time-series in the Balearic Sea (Western Mediterranean): Variability during the decade 1994-2003. Progress in Oceanography 74: 329354.

67. Tadokoro K, Chiba S, Ono T, Midorikawa T, Saino T (2005) Interannual variation in Neocalanus biomass in the Oyashio waters of the western North Pacific. Fisheries Oceanography 14: 210-222.

68. Chiba S, Tadokoro K, Sugisaki H, Saino T (2006) Effects of decadal climate change on zooplankton over the last 50 years in the western Subarctic North Pacific. Global Change Biology 12: 907-920.

69. Robinson LM (2011) Pushing the limits in marine species distribution modeling: lessons from the land present challenges and opportunities. Global Ecology and Biogeography 20: 789-802.

70. Hansen BW, Drillet G, Kozmer A, Madsen KV, Pedersen MF, e al. (2010) Temperature effects on copepod egg hatching: does acclimatization matter? Journal of Plankton Research 32: 305-315.

71. Hansen BW, Drillet G (2013) Comparative oxygen consumption rates of subitaneous and delayed hatching eggs of the calanoida copepod Acartia tonsa (Dana). Journal of Experimental Marine Biology and Ecology 442: 66-69.

72. Chiba S, Batten SD, Yoshiki T, Sasaki Y, Sasaoka K, et al. (2015) Temperature and zooplankton size structure: climate control and basin-scale comparison in the North Pacific. Ecology and Evolution 5: 968-978.

73. Ban S, Minoda T (1994) Induction of Diapause Egg Production in Eurytemora affinis by Their Own Metabolites. Hydrobiologia 293: 185-189.

74. Lin KY, Sastri AR, Gong GC, Hsieh CH (2013) Copepod community growth rates in relation to body size, temperature, and food availability in the East China Sea: A test of metabolic theory of ecology. Biogeosciences 10: 1877-1892.

75. Miliou $H$ (1996) The effect of temperature, salinity and diet on final size of female Tisbe holothuriae (Copepoda, Harpacticoida). Crustaceana 69: 742-754

76. McAllen R, Block W (1997) Aspects of the cryobiology of the intertidal Harpacticoid copepod Tigriopus brevicornis. Cryobiology 35: 309-317.

77. McAllen RJ, Taylor AC, Davenport J (1998) Osmotic and body density response in the harpacticoid copepod Tigriopus brevicornis in supralittoral rock pools. Journal of the Marine Biological Association of the United Kingdom 78: 1143-1153.

78. McAllen R, Taylor AC, Davenport J (1999) The effects of temperature and oxygen partial pressure on the rate of oxygen consumption of the high-shore rock pool copepod Tigriopus brevicornis. Comparative Biochemistry and Physiology a-Molecular and

1. Integrative Physiology 123: 195-202.

79. Wells JBJ (2007) An annotated checklist and keys to the species of Copepoda Harpacticoida (Crustacea). Zootaxa 1568: 1-872.
80. Pagano M, Kouassi E, Saint-Jean L, Arfi R, Bouvy M (2003) Feeding of Acartia clausi and Pseudodiaptomus hessei (Copepoda: Calanoida) on natural particles in a tropical lagoon (Ebrie, Cote d'Ivoire). Estuarine, Coastal and Shelf Science 56: 433-445.

81. Marques SC, Azeiteiro UM, Marques JC, Neto JM, Pardal MA (2006) Zooplankton and ichthyoplankton communities in a temperate estuary: spatial and temporal patterns. Journal of Plankton Research 28: 297-312.

82. Leandro SM, Tiselius P, Queiroga H (2014) Spatial and temporal scales of environmental forcing of Acartia populations (Copepoda: Calanoida) in the Canal de Mira (Ria de Aveiro, Portugal). ICES Journal of Marine Science 71: 585-596.

83. Cervetto G, Pagano M, Gaudy R (1995) Adaptation of the copepod Acartia clausi to salinity variations. Journal de Recherche Océanographique 20: 42-49.

84. Cervetto G, Gaudy R, Pagano M (1999) Influence of salinity on the distribution of Acartia tonsa (Copepoda, Calanoida). Journal of Experimental Marine Biology and Ecology 239: 33-45.

85. Dutz J, Christensen AM (2018) Broad plasticity in the salinity tolerance of a marine copepod species, Acartia longiremis, in the Baltic Sea. Journal of Plankton Research 40: 342-355.

86. Mauchline J (1998) The biology of Calanoid copepods. In: JHS Blaxter, AJ Southward, PA Tyler (Eds), Advances in Marine Biology, Academic Press, London, UK.

87. Wyckmans M, Chepurnov VA, Vanreusel A, De-Troch M (2007) Effects of food diversity on diatom selection by harpacticoid copepods. Journal of Experimental Marine Biology and Ecology 345: 119-128.

88. Ustach JF (1982) Algae, bacteria and detritus as food for the harpacticoid copepod, Heteropsyllus pseudonunni Coull and Palmer. Journal of Experimental Marine Biology and Ecology 64: 203-214.

89. Pace MC, Carman KR (1996) Interspecific differences among meiobenthic copepods in the use of microalgal food resources. Marine Ecology Progress Series 143: 77-86.

90. De Troch M, Chepurnov V, Gheerardyn H, Vanreusel A, Olafsson E (2006) Is diatom size selection by harpacticoid copepods related to grazer body size? Journal of Experimental Marine Biology and Ecology 332: 1-11.

91. Wang GZ, Xu J, Zeng CS, Jia QL, Wu LS (2015) Pelagic microalgae as suitable diets for the benthic harpacticoid copepod Tigriopus japonicus. Hydrobiologia 762: 81-88.

92. Jiang X, Wang G, Li S, He J (2007) Heavy metal exposure reduces hatching success of Acartia pacifica resting eggs in the sediment. Journal of Environmental Sciences 19: 733-737.

93. Wright DA, Savitz JD, Dawson R, Magee J, Smucker RA (1996) Effect of diflubenzon on the maturation and reproductive success of the copepod Eurytemora affinis. Ecotoxicology 5: 47-58.

94. Rejomon G, Balachandran KK, Nair M, Joseph T, Kumar PKD, et al. (2008) Trace metal concentrations in Zooplankton from the Eastern Arabian Sea and Western Bay of Bengal. Environmental Forensics 9: 22-32.

95. Chen Y (2016) Oxidative damage effects in the calanoid copepod Pseudodiaptomus annandalei sewell experimentally exposed to metal additions. Fresenius Environmental Bulletin 25: 1978-1987.

96. Kim BM, Rhee JS, Jeong CB, Seo JS, Park GS, et al. (2014) Heavy metals induce oxidative stress and trigger oxidative stress-mediated heat shock protein (hsp) modulation in the intertidal copepod Tigriopus japonicus. Comparative Biochemistry and Physiology C-Toxicology and Pharmacology 166: 65-74. 
97. Lee KW, Raisuddin S, Hwang DS, Park HG, Lee IS (2007) Acute Toxicities of trace metals and common Xenobiotics to the marine copepod Tigriopus japonicus: Evaluation of its use as a benchmark species for routine ecotoxicity tests in Western Pacific coastal regions. Environmental Toxicology 22: 532-538.

98. Hook SE, Fisher NS (2001) Reproductive toxicity of metals in calanoid copepods. Marine Biology 138: 1131-1140.

99. APHA (2012) Standard Methods for the Examination of Water and Wastewater. In: (21 nd edn.), American Public Health Association/ American Water Works Association/Water Environment Federation Washington, USA.

100. Brugnano C, Granata A, Guglielmo L, Minutoli R, Zagami G (2014) Fecundity and development of the bentho-pelagic copepod Pseudocyclops umbraticus: Effects of temperature. Aquatic Biology $20: 245-254$
101. Drira Z, Kmiha-Megdiche S, Sahnoun H, Hammami A, Allouche N, et al. (2016) Assessment of anthropogenic inputs in the surface waters of the southern coastal area of Sfax during Spring (Tunisia, Southern Mediterranean Sea). Marine Pollution Bulletin 104: 355-363.

102. Masri N (2005) Bioindicatrices des stress environnementaux marins de la 542 côte Sud de Sfax. Exemples des Foraminifères benthiques actuels. Université de Sfax, Tunisie.

103. Shannon C E, Weaver G (1949) The mathematical theory of communication. In: University of Illinois Press, Urbana, Chicago, US, p. 118.

104. Zheng Z (1989) Marine planktology. In: China Ocean Press, Beijing, China.

\section{Your next submission with Juniper Publishers will reach you the below assets}

- Quality Editorial service

- Swift Peer Review

- Reprints availability

- E-prints Service

- Manuscript Podcast for convenient understanding

- Global attainment for your research

- Manuscript accessibility in different formats

( Pdf, E-pub, Full Text, Audio)

- Unceasing customer service

Track the below URL for one-step submission https://juniperpublishers.com/online-submission.php 